\title{
42-İskendername ve Mahzen-i Esrar’a göre Nizâmî’de evrensel eşitlik ideali
}

\section{Tuncay SAYGIN2}

\section{Mehmet Mustafa KARACA3}

\begin{abstract}
APA: Saygın, T. \& Karaca, M. M. (2022). İskendername ve Mahzen-i Esrar'a göre Nizâmî'de evrensel eşitlik ideali. RumeliDE Dil ve Edebiyat Araştırmalar Dergisi, (26), 711-719. DOI: 10.29000/rumelide.1075630.
\end{abstract}

\section{$\ddot{O}_{\mathbf{z}}$}

Düşünce tarihinin en başından beri iki figür öne çlkar. Bu figürlerden biri şair diğeri ise filozoftur. Şairi ve filozofu birbirine yakınlaştıran önemli bir nokta ise ideal tutkularıdır. Şair ideal sözü ararken; filozof ise ideal varlı̆̆ arar. Şair ve filozof her zaman çok iyi anlaşamazlar fakat her zaman birbirlerine çok şey borçludurlar. Nizâmî Gencevî, felsefe ile şïrin birbirini tamamlayan şeyler olduğunu düşünür ve şiir ile felsefeyi buluşturmayı bu yolla da ideal varlığın ideal söz ile dile gelmesine aracılık etmeyi amaçlar. 1141-1214 yılları arasında yaşadığı tahmin edilen Nizâmî, epik ve lirik şiirin önemli isimlerinden olup hamse türünün de kurucularından kabul edilmektedir. Nizâmîyyi şair kimliğinin dışında özellikle İskendername ve Mahzen-i Esrar adlı eserlerindeki yaklaşımları ile bir düşünür ve filozof olarak da değerlendirmek mümkündür. Bu yazıda daha çok İskendername ve Mahzen-i Esrar adlı iki eserini merkeze alarak Nizâmı̂’nin hümanizma temelinde, evrensel bir eşitlik inancına sahip olduğu ileri sürülecek ve bunu nasıl savunduğu gösterilmeye çalışılacaktır.

Anahtar kelimeler: Nizâmî Gencevî, İskendername, Şiir ve Felsefe, Eşitlik, Hamse

\section{The ideal of Universal Equality in Nezami's Iskendername (The Book of Alexander) and Makhzan al-asrār (The Treasury of Mysteries)}

\begin{abstract}
Two important figures come into promining during the history of thougth. One is philosopher and the other is poet. Key point which bring them closer to each other is their ideal passions. While the poet is looking for an ideal word, the philosopher seeks the ideal being. The poet and the philosopher don't always get along very well, but they always owe a lot to each other. Nizâmî Gencevî thinks that philosophy and poetry accomplished each other and aims to bring poetry and philosophy together and in this way to mediate the expression of ideal existence with ideal words. Nizâmî, who is estimated to have lived between 1141-1214, is one of the important figures of epic and lyric poetry and he accepted as one of the founders of the hamse genre. Apart from his identity as a poet, it is possible to accept Nizâmî as a thinker and philosopher, especially with his thoughts in his works titled Iskendername (The Book of Alexander) and Makhzan al-asrār (The Treasury of Mysteries). In this
\end{abstract}

Bu metin “Nizâmide Evrensel Eşitlik İdeali” başlığıyla 22.06.2021'de Gence(Ganja)'de düzenlenen Universal ideas in the works of Nizami Ganjavi adlı etkinlikte Tuncay Saygın tarafından sunulmuş olan özet bildirinin genişletilerek ortak kaleme alınmış bir şeklidir.

Doç. Dr., Aydın Adnan Menderes Üniversitesi, Fen-Edebiyat Fakültesi Felsefe Bölümü (Aydın, Türkiye), tsaygin@adu.edu.tr, ORCID ID: 00oo-0002-7854-8987 [Araștırma makalesi, Makale kayıt tarihi: 04.01.2022-kabul tarihi: 20.02.2022; DOI: 10.29000/rumelide.1075630]

3 Dr. Öğr. Üyesi, Aydın Adnan Menderes Üniversitesi, Fen Edebiyat Fakültesi, Türk Dili ve Edebiyatı Bölümü, Eski Türk Dili ABD (Aydın, Türkiye), mmkaraca@adu.edu.tr, ORCID ID: o0oo-0001-9763-3151

Adres | Address

RumeliDE Dil ve Edebiyat Araştırmaları Dergisi Osmanağa Mahallesi, Mürver Çiçeği Sokak, No:14/8 Kadıköy - İSTANBUL / TÜRKIYE 34714 e-posta: editor@rumelide.com tel: $+905057958124,+902167730616$

RumeliDE Journal of Language and Literature Studies

Osmanağa Mahallesi, Mürver Çiçeği Sokak, No:14/8

Kadıköy - ISTANBUL / TURKEY 34714

e-mail: editor@rumelide.com

phone: +90 $5057958124,+902167730616$ 
article, we will argue that Nizâmî had a belief in universal equality on the basis of humanism, and we will try to show how he defended it.

Keywords: Nezâmî Ganjavî, İskendername (The Book of Alexander), Poem and Philosophy, Equity, Hamse

\section{Giriş}

Nizâmî’nin doğum ve ölüm ylları net olarak bilinmemekle birlikte onun aşağı yukarı 1141-1145 yıllarında doğduğu ve 1201-1214 ylları arasında da öldüğü düşünülmektedir. Nizâmî, "Firdevsi’nin destansı şiir türünü zirveye taşımakla kalmamış, manzum aşk hikâyelerinin en büyük üstadı" unvanını kazanmış ve aynı zamanda hamse türünü kurmuş bir kişi olarak tanınmıştır (Kanar 1997: 183). Hamse'nin beş mesnevisi de kendisini takip edenlerce defalarca taklit edilmiştir. Bununla beraber, "Nizâmî̀nin eşsiz cinaslar ve ince zekâyı yansıtan retorik oyunlarıyla dolu incelikli dilini gölgede bırakan çıkmadı” (Schimmel 2017: 63). Gencevî̀yi şair kimliğinin dışında özellikle İskendername ve Mahzen-i Esrar adlı eserlerindeki yaklaşımları ile bir düşünür ve filozof olarak da değerlendirmek mümkündür.

Nizâmî Gencevî, çocuk denilecek yaşta anne babasını kaybetmiş olmakla beraber oldukça iyi bir eğitim almıştır. Onun eserleri ontolojik bir temel üzerine inşa edilmiştir. Nizâmî, Tanrı'yı her şeyin kendisine muhtaç olduğu mutlak bir varlık olarak görür ve kendi varlı̆̆ının da ona borçlu olduğunu ifade eder. Hamse'nin ilk metni olan Mahzen-i Esrar'da bu, şu şekilde dile getirilir:

"Yüce Allah ki, varlı̆̆ı bütün varlıklardan öncedir. Yerlerin, göklerin yüce yaratıcısıdır. Kıdem cihanın başbuğudur. Kalemin boynuna muska bağlayandır." (Sevsevil 2012: 13). Allah, varlıktan haberdar eden, bilgiyi lütfeden, ahlak ve hikmeti öğretendir. Mutlak olduğu için "Onun katında varlık, yokluk, alçaklık, yükseklik birdir. Olmuş, olmamış hep aynı şeydir.” (Sevsevil 2012: 13). Allah varlık zincirini birbirine bağlamış ve belirli biçimlerde ve güzellikte yaratmıştır. Dünyayı ve canlılığı da böylesi bir nizama tabi kılmıştır.

Bazıları onun felsefedeki yetkinliğini şöyle dile getirmiştir: "Nizâmî, hikmet ve felsefede o kadar yükselmiştir ki eğer şiir ile iştigal etmeseydi, o parlak şöhretini felsefede yapardı.” (Sevsevil 2012: 7). İlimlerde böylesi derinlik kazanmış olmasının yanı sıra Nizâmî, karakteriyle de örnek bir kişi olarak kabul görmüştür. Nizâmînnin eserlerinden, onun dünya nimetlerine yüz çevirdiği ve zahidâne bir yaşam sürdüğü anlaşılmaktadır. Nizâmî, Mahzen-i Esrar başta olmak üzere çoğu eserinde mal ve mülkün, dünya hayatının geçiciliğine vurguda bulunur ve bununla ilgili edebî hikâyeler anlatır. Bu hikâyeler kişileri hak yola davet etmek üzere anlatılmışlardır. Nedir bu hakikat yolu ve nasıl anlatılabilir?

\section{Hakikat'i aramak: Șair ve filozof}

Düşünce tarihinin en başından beri iki figür öne çıkar. Biri şair diğeri ise filozof figürüdür. Şairi ve filozofu birbirine yakınlaştıran önemli bir nokta ideal tutkularıdır. Şair ideal sözü ararken, filozof ideal varlığı veya varlığın hakikatine ulaşmanın yollarını arar. Şair ve filozof her zaman çok iyi anlaşamazlar fakat her zaman birbirlerine çok şey borçludurlar. Nizâmî Gencevî, felsefe ile şiirin birbirini tamamlayan şeyler olduğunu düşünür. Dolayısıyla şiir ile felsefeyi buluşturmayı bu yolla da ideal varlığın ideal söz ile dile gelmesine aracılık etmeyi amaçlar.

Nizâmî, Hüsrev ile Şirin'de kendi amacının hakikate ermek olduğunu hemen en başında şu şekilde Tanrı'ya dua ederken dile getirir: “Allahım! Muvaffakiyet kapısını aç ve Nizâmî̀ye hakikat arama yolunu

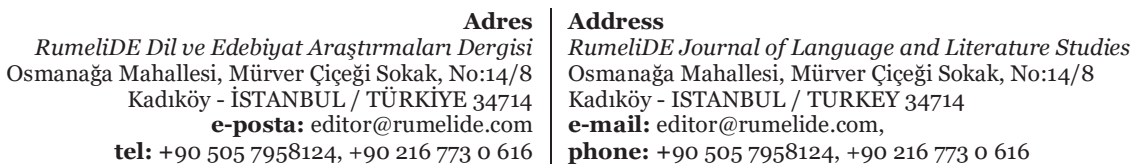


göster. Bana bir gönül ver ki, seni yakınen bilmeye layık olsun, bir dil ver ki, daima seni ansın, övsün.” (Sevsevil 2012: 19). Onun için eserlerinin her birinde amaç hakikate yaklaşmak ve Allah’ın parlak nuruna yakınlaşmaktır. Bunun gerçekleşmesi için kullanılacak anahtar ise "söz"dür. Nizâmî, Mahzen-i Esrar'da sözün hikmetini şu şekilde açıklar. "Söz, gönüllere ses vermedikçe çamurdan yaratılmış ten içinde can yerleşmedi. Kalem, harekete başlayınca cihanın gözü de sözle açıldı. Sözsüz âlemin sesi çımaz." (Gençosman 2014: 43). Onun ifadesiyle "sözden daha keskin bir şey yoktur. Düşüncenin başı, sayının sonu hep sözdür.” (Gençosman 2014: 43). O hâlde varlığın anlamını bize veren şey sözdür ve bu nedenle her şeyin hikmeti ancak söz ile anlaşılır. Böyle olduğu için söz kendisi dışında bir şeye ihtiyaç duymaz. Nizâmî’ye göre sözün değeri hiçbir şeyle ölçülmez ancak her şeyin kıymeti söze bağlıdır. Sözün önemini ve mutlaklığını şöyle özetler: "Hiç kimse söz mertebesinden daha yüce bir mevkie oturamaz. Bu mülkün devleti sözlerdir.” (Gençosman 2014: 44).

Nizâmî nazarında, şaire düşen görev ise söze ideal ölçüyü vermek ve buna göre hakikati dile getirmektir. Şair hakikati dile getirdiği için onun yeri peygamberlerin yanıdır. "Söz erenleri birer sır perdesidirler, peygamberin ışı̆̆ından birer gölgedirler." (Gençosman 2014: 45). "Peygamberler hakikatin özü, şairler de dış kabuğudur." (Gençosman 2014: 45). Şairin böyle kutlu bir vazifesi olduğu için ahlakı ve kişiliği de buna yaraşır olmalıdır. Onun ifadesiyle, "söz ülkesinde diz çökmüş olanlar, her eşiğe baş koymazlar." (Gençosman 2014: 45). Nizâmî’ye göre söz en değerli olan şeydir ve bu nedenle şair soylu bir duruş sergilemelidir. Onun mutlak olarak mütevazı, mahcup ama yine de uyanık ve aklı başında olması gerekir. İhtiyatlı ve dikkatli olmalıdır ki yüksek fikirlere ulaşabilsin (Gençosman 2014: 46-47). Elbette burada söz ile ifade edilen şey yalnızca ses ile ortaya çıan ifadeden ibaret değildir. Herakleitos'un terminolojisindeki logos ile oldukça benzer bir şekilde kullanılan söz, evrende mevcut olan düzenin dile gelişidir. Bu nedenle onu evrenin gizli düzeni şeklinde görmek mümkündür. Hiç bir şeyin "sözden yüce bir mevkie sahip olamayacağı” iddiası, sözün evrenin mutlak kanunu olduğu anlamına gelecektir.

Nizâmî açısından filozof tıpkı şair gibi bir hakikat yolcusudur. Filozoflara dair en fazla değerlendirmeyi ve felsefeyi ele alma şeklini açıcça görebildiğimiz İskendername'nin İkbalname kitabında farklı filozof tiplemeleri olarak en çok Aristoteles, Eflatun ve Sokrates'i konu edinir. Burada kendisinin akıl ile dost olduğu için filozoftan ders aldığını söyler:

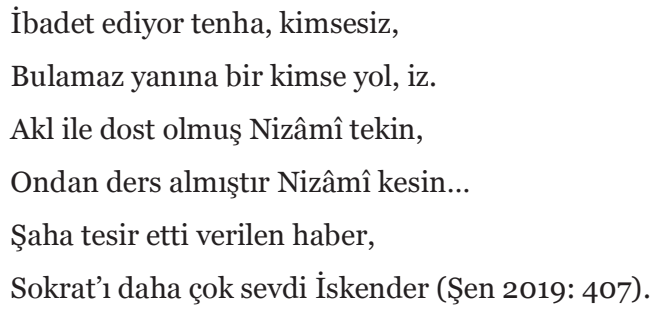

Bilindiği üzere,

“İkbalname’de İskender’in etrafina topladığı Erestu (Aristoteles), Valis, Belinas, Sokrat (Sokrates), Ferfuriyus (Porphyrius), Eflatun (Platon) ve Hürmüz gibi filozoflarla evren, yıldızlar, yeryüzünde hayat, hayatın oluşumu, ölüm vb. konularda sohbetleri yer alıyor; bu sohbetlerde insanlığın amacı ve görevleri, insanlar arasındaki ilişkiler ve bunların kamu yararına hizmet etmesi gerektiği hakkında ilginç fikirler ve çözüm yolları ileri sürülüyor.” (Nahmedov ve Saygın 2012: 128).

Nizâmî, burada söz konusu filozofları farklı farklı şekillerde değerlendirir ve genel olarak onları bir hakikat elçisi gibi görür. Nizâmî’nin filozof tiplemelerinden biri olarak Aristoteles bir tür öğrencidir. Öğrenmeye niyetli ancak zaman zaman kendini beğenen bir figür olarak Aristoteles, yine de bir ışık

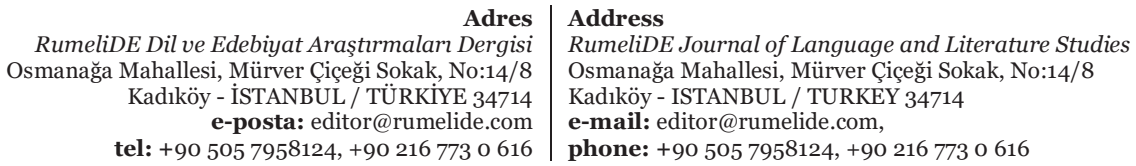


timsali yön vericidir. Bununla birlikte Nizâmî, bilgide en yüce makam olarak yalnızca Tanrı’yı görür ve filozofun bilgisinin bir sınırı olduğunu düşünür. Yaratılmışlar arasında üstünlük yine de ilim iledir.
“Âlimdir gözümde en aziz insan!
İlimle, hünerle!-Başka tür hiç kes
Kimseye üstünlük eyleye bilmez!
Rütbeler içinde seçilir bili,
Herkesten yücedir âlimin yeri!”
Böyle karar verdi; yanında ancak,
Herkes öz ilmiyle bir yer tutacak.
Herkes ilme, fenne eyledi rağbet,
Çünkü ilme teşvik ederdi devlet.
İlme kıymet koydu büyük hükümran,
İlm ile yüceldi dünyada Yunan (Şen 2019: 405).

Íkbalname'de Aristoteles, "kendisini herkesten yukarı tutan" şeklinde değerlendirilirken, Eflatun ise daha yüce bir makamda değerlendirilir. Eflatun'u bir tür gönül ehli olarak anan Nizâmî, onu bir Anka kuşuna benzetir ve her türlü canlıya hükmeden bir saz icat eden kişi olarak hikâye eder. Bu şekliyle, her şeyin sırrına erme makamı için musikinin kullanılması ise temelde filozof ve şairin buluştuğu ortak noktadır:

Eflatun yaratmış öyle bir perde

Ki, onu bir bilen yoktur hiç yerde (Şen 2019: 400).

Perde sembolik dil itibariyle geçişi, değişebilirliği, gizli olanın aralanışını ifade eden ve anlamca çok zengin bir semboldür. Bu sembolün müzikal bir terim şeklinde kullanımında da denge ve ahenk vurgusu söz konusudur. Nizâmî, şair ve filozofu birbirine oldukça yakınlaştırır ve onlar arasındaki en özel buluşma noktası olarak da evrenin sırrını görebilmelerini görür. Her ikisi de evrende mevcut olan ahengi bilirler, dengenin farkındadırlar, şeylere hükmetmenin imkânın söz ve sanat olduğunun bilincindedirler.

Ona göre bu farkındalık ve bunların bilincinde olma hâli filozofu da şairi de bir zahit yaşamına yönlendirecektir. Nizâmî, kendi yaşamında buna her zaman dikkat etmiş ve bunu da hiçbir zaman bir saray şairi olmayarak göstermiştir. Eserlerinde de bu ahlakı benimsediğini açık açı gösterir. Bilgen'in ifadesiyle,

“Gerek ilk mesnevisi olan Mahzan al-Asrâr'daki gerekse diğer eserlerindeki ifadelerinden, Nizâmî’nin, dünya nimetlerine yüz çevirerek zahidâne bir yaşam sürdüğünü ve tasavvufa yöneldiğini görmekteyiz. Şair özellikle, nispeten genç bir yaşta kaleme aldı̆̆ı Mahzan al-Asrar'da ahlakî ve tasavvufî konulara ilişkin görüşlerini, riyazet ehli bir sufinin içtenliği ile ifade ve telkin etmiştir.” (Bilgen 1991: 16).

İdeal bir ahlak için dünya işlerinden vazgeçmeyi telkin eden Nizâmî, filozof hayatlarından ise Sokrates’in hayatını buna örnek gösterir. İkbalname'de İskender'le Sokrates'in hikâyesinde zahitliği ve Sokrates’in zahit yaşamını şu şekillerde tasvir eder:

Bir alim diyor ki: Bir zaman Yunan

Ehli uğraşmamış asla bir işe,

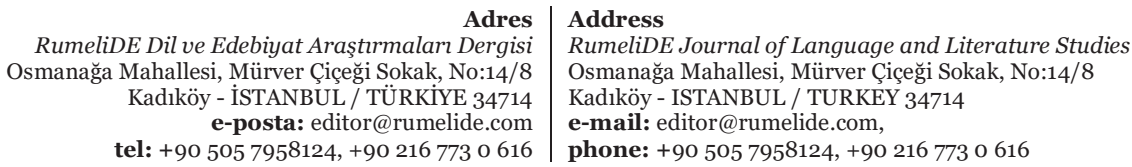


Herkes zahitliği etmişti peşe;

Dünyada göz yumup istirahate,

Onlar hor bakırdı zevke, şehvete,

Çok bilmek, az yemek yolu tutarak,

Herkes riyazetle meşguldü ancak (Şen 2019: 405).

Quluzade'nin değerlendirmesiyle, Nizâmî için, Dünya nimetlerinden el çekmek insana öz değerini bulmak ve korumak için lazımdır. Bu nedenle de Nizâmî'nin kahramanlarında terki-dünya etmeye meyletme buradan doğar. Nizâmî’nin kahramanları insanın liyakatini ve gururunu korumak adına züht hayatına meyletmişlerdir (Quluzade 2004: 8). Sokrates'in hikâyesi bunun iyi örneklerindedir. Hikâyenin ilerleyen dizelerinde Sokrates'in yaşam şeklini ve nasıl dünyevi zevklerden vaz geçmiş bir yaşam sürdürdügünü4 ise şu şekilde anlatır Nizâmî:

Düzdür, sert olsa da Sokrat'ın sözü,

Beğendi onları İskender özü.

Bildi, onu ancak halvette görür,

Piyade yollandı ora İskender.

Gördü ki yaşıyor çok perişan, tek,

Harabe köşede bir hazine tek.

Dünya işlerine yummuş gözünü,

Hücreye çekmişti Sokrat özünü (Şen 2019: 409).

Şairin gözünde Sokrates'in hayatı İskender'in hayatından daha yücedir. Sokrat, yetinmeyi bilendir. Hükümdar ise hırshidır ve dünyaya malik de olsa gözü doymamıştır. Bu nedenle ilerleyen satırlarda Nizâmî, Sokrates'in dilinden filozofun hükümdardan nasıl üstün olduğunu ise şöyle dile getirir:

"Ben ferman verenim, sen ferman alan!"

Şaha öfke geldi, söyledi ona:

"Bu örtülü sözden de, nedir mana?"

Yine cevap verdi akıllı Sokrat:

"Dinle, manasını derim bu saat:

Benim heves adlı bir nökerim var,

O daim önümde fermanla durur.

Aynı on nökerin nökerisin sen,

Bana kul olana kulluk edensin!" (Şen 2019: 409).

Nizâmî’nin İskendername’yi Büyük İskender’i övmek üzere yazdı̆̆ı dikkate alınır ve bu ifadeler bu bilgi ışığında değerlendirilirse, onun övgüyü şahtan çok üstün ahlakı olan filozofa yaptığı anlaşlacaktır. Sokrates’in kanaatkârlığı onu yüce kılır. Leylâ ile Mecnun'da kanaat şu sözlerle övülür: "Kanaatkâr insan hep saygı görür/Kanaatın velâyet olduğunu görür.” (Tokmak 2013: 229). Gencevî’nin gözünde insanların en yücesi en ahlaklı olanıdır. En ahlaklı olan ise bu dünyanın geçici heveslerine değer

$4 \quad$ Tarihi bir bilgi ile değerlendirildiğinde Nizâmînnin ifade ettiği gibi Sokrates’in dünyadan el etek çeken biri olmadığ 1 rahatlıkla görülebilmektedir. Hatta Sokrates çăgdaşları olan Sofistlere karșı Atina düzenini korumak üzere gençleri eğiten, onlara felsefe öğretme heyecanı duyan, Atina’nın ahlaki ve siyasi yapısı adına verdiği mücadele ile canından olmuş bir düşünürdür. Bu nedenle Sokrates’in böyle bir manada zahid olmadığı açıtır. Nizâmî’nin zühd olarak gördüğü ise ancak dünyevi servetten vaz geçme olabilir.

RumeliDE Dil ve Edebiyat Araştırmaları Dergisi Osmanağa Mahallesi, Mürver Çiçeği Sokak, No:14/8 Kadıköy - İSTANBUL / TÜRKIYE 34714 el: +90 -posta: editor@rumelide.com
Address

RumeliDE Journal of Language and Literature Studies

Osmanağa Mahallesi, Mürver Çiçeği Sokak, No:14/8

Kadıköy - ISTANBUL / TURKEY 34714

e-mail: editor@rumelide.com,

phone: +90 5057958124 +90 2167730616 
vermeyen, arzularına ve isteklerine kulluk etmeyendir. İnsanın arzu ve istekleri onun hayvani yönleridir. Bunlara teslim olanlar gaflettedir ve gaflet uykusundadır. Şaire düşen ise tıpkı filozofun yaptı̆̆ı gibi onları bu gafletten uyanmaya çă̆ırmaktır.

Nizâmî, Mahzen-i Esrar'da insanın varlık zincirindeki yerini ve gafletten uyanmasının şartlarını şöyle anlatır:

"Ey gaflet uykusu içinde hoşnut yaşayan Ademoğlu! Yiyip içmede senin öküzden, eşekten ne farkın var? Yerde olup bitenlerden habersizsin. İşi nazar ve akıl sahipleri anlayabilir. Gafillerle duygusuzların, zamanenin gamıyla ne ilgisi var?” (Gençosman 2014: 127).

Devamında insanı şerefli kılan ve yücelten yönün akıl olduğu, insanın ancak akıl yolundan giderek ve aklın aydınlığını seçerek gafletten uyanabileceğini belirtir. İnsan "başı gökte, ayağı çamurda" olan bir varlıktır. Kişi "kendinin bedenin garaz kirlerinden temizlemeli" ve doğrulukla hareket etmelidir. Zira, "Yiğitin zırhı onun doğruluğudur" ve herkes günü geldiğinde hesabını verecektir (Gençosman 2014: 127129). Bu nedenle uyanmış kişi ahlaki doğruluktan sapmamalıdır.

"Sana gizli işlerin açık gösterilecek, az verdiklerin, çok aldıkların meydana çıkacak. Kendini alıșveriște günahkâr etme, çok vermeye az almaya çalıș. Gül eğriliği yüzünden kucağında dikenler buldu, şeker kamışı doğrulukla o tatlılığı elde etti. Doğruluğun bayrak çektiği yerde hakkın yardımı imdada koşar." (Gençosman 2014: 129).

Gencevî’nin bu değerlendirmelerinde gördüğümüz temel hususlardan birisi ahlak ve aklın merkezî önemde olduğudur. Şair ve filozofun yüceliği ve şerefi insani yücelikte gizlidir. Sırra eren insan, dünyaya ve dünyevi arzulara sırtını döner. Filozof ve şairi üstün kılan ise bu sırra ermişliktir. Sırra eren, her şeyin varlığını Tanrı'ya borçlu olduğunu ve Tanrı'nın hükmünün dışında bir hüküm olmadığını bilir. Bu anlayışları ile Nizâmî’nin bir tür evrensel hümanizma5 tezine sahip olduğu ifade edilebilir.

"Ortaçağ hümanizminin zirvesi saylacak bu eserlerde şah, çoban, hizmetçi, bilgin, asker, şair, bahçıvan, filozof, komutan, mimar, çiftçi ve diğer insanlar arasında irkî, dinî, kavmî, sosyal ayırım yapılmaksızın, onlara topluma yararlılık derecesine göre değer verilmektedir. Bu anlamda Genceli’nin temelde eşitlikçi bir görüşe sahip olduğu görülmektedir.” (Nahmedov ve Saygın 2012: 127).

\section{Eşitlik ideali}

Nizâmî’nin İkbalname'de anlattığı hayalî devlet onun düşüncesinin olgun bir ürünüdür ve aynı zamanda toplumsal hayata dair inancının bir özetidir. Bu mısralarda anlatılan bir ütopya devleti olduğu kadar aynı zamanda bir ahlaki idealdir. Ayrıca İnsanların iyi yaşam için nelere dikkat etmesi gerektiğinin de bir açıklamasıdır. ${ }^{6}$

Nizâmî, İskender'in kuzeye ve Yecüc Seddi’ne ulaşmasını anlattıktan hemen sonra bir güzel diyara ulaştığını hikâye eder. Burada gördüğü hayat bir tür cennet yaşamıdır. Tabiat tamamen başka türlüdür. Mal ve mülkler için sınır, çeper yoktur, sürüler çobansızdır. Kapısı ve kilidi olmayan bu memlekette varlık çok, açlık ve eksiklik yoktur (Şen 2019: 491-492). O diyarın halkı İskender’i karşılar ve sofraya

5 Nizâmî’nin düşüncesi kuşkusuz batılı bir felsefi hümanizma değildir bununla beraber sadece insana insan olarak değer veren bir anlayıș olduğu için hümanizma olarak anılabilir. İslam dünyasında yerleşik olan bir düșüce olarak "müsammaha" kuşkusuz ki Nizâmî’nin düşüncesi adına daha isabetli bir adlandırma olacaktır.

6 Bu ütopya devletinin bir açıklaması için bkz. Ahmad Nahmedov; Tuncay Saygın, “Doğu'dan Bir Ütopya Kenti: Genceli Nizamî̀nin İs-kendername Eserinde İdeal Kent.” İdealkent, 3 (5).

Adres | Address

RumeliDE Dil ve Edebiyat Araşttrmaları Dergisi Osmanağa Mahallesi, Mürver Çiçeği Sokak, No:14/8 Kadıköy - İSTANBUL / TÜRKIYE 34714 e-posta: editor@rumelide.com

RumeliDE Journal of Language and Literature Studies Osmanağa Mahallesi, Mürver Çiçeği Sokak, No:14/8 Kadıköy - ISTANBUL / TURKEY 34714

phone: +90 $5057958124,+902167730616$ 
buyur eder. Bunun üzerine gelişen sohbette İskender, bu memleketin hikmetini onlara sorar. Onlar da şöyle anlatır:

Bizim güzeranı sordu hükümran,

Buyurup dinlesin, biz edek beyan;

Doğrusu şudur ki bizler kadimden

Bu dağı, bu çölü etmişiz mesken.

Fakir bir tayfayız, üstelik dindar,

Düzlükten geçmeyiz asla kll kadar.

Eğri dolanmakla yoktur işimiz,

Düzlükten başka yol tanımayız biz.

Eğrilik yoluna çekmişiz hisar,

Düzlükle olmuşuz azaptan kenar.

Yalan getirmeyiz biz dilimize,

Eğri uyruklar da görünmez bize.

Faydasız etmeyiz hiç sorgu sual,

Çünkü Allaha da hoş gitmez bu hal.

Allah'tan ne gelse, ederiz şükür,

Çünkü na-razllık na-şükürlüktür.

...

Acizin derdine ederiz çare,

Kurtarırız onu düşerse dara.

...

Bizde beraberdir herkesin varı,

Beraber böleriz bütün malları.

...

Bekçisizdir otlar, bizim mal-davar.

Bizim çocukları büyütür Allah,

Nahıra şir, peleng dokunmaz asla.

Bizim koyuna değmez canavar (Şen 2019: 492-493).

Burada ortaya çıkan yaşantı, mülkiyetin olmadı̆̆ı ve insanların sadece iyi ahlak üzerine hareket ettikleri bir yaşantıdır.7 Bu yaşantıyı mümkün kılan şey ise kişilerin sahip olduğu iyi niteliklerdir. Daha başka eserlerinde de Nizâmînnin ısrarla üzerinde durduğu şey iyi hayatın ancak ahlak ile mümkün olduğudur. Ĕger insanlar yetinmeyi bilir, Allah'a tam olarak iman ederler ve ona güvenerek hareket ederlerse her işleri yolunda gider. İnsanların böyle yaşamaları için Allah'ın kulu olduklarını bilmesi ve buna göre yaşamaları gerekir. İnsanlar eğer Allah’a teslim olmuşlarsa kötülük yapamazlar. Kötülük yapmazlarsa

\footnotetext{
Nizâmî̀nin burada savunduğu mülkiyetin ortaklığı tezi İslam Hukukunda olmayan bir anlayışs şeklidir. Bu düşünce onun kișiliğine yordanabilir. Nizâmînin ideal toplum tasarımının en önemli kaynağı olan, Farabi'nin El-Medinetül Fazıla'sında, Aristotelesçi politik anlayış yerine Platoncu Politik tutum benimsenmiş görünmektedir. Her ne kadar Aristotles, Platon'un savunduğu mülkiyet ortaklı̆̆ını eleştirmiş olsa da bir Aristotelesçi olan Farabi bu konuda Platon’un düşüncesine yakın durmuştur. Nizâmî de bu hususta Farabi'yi takip etmiştir.

RumeliDE Dil ve Edebiyat Araşttrmaları Dergisi Osmanağa Mahallesi, Mürver Çiçeği Sokak, No:14/8 Kadıköy - İSTANBUL / TÜRKIYE 34714 e-posta: editor@rumelide.com tel: +90 $5057958124,+902167730616$

Address

RumeliDE Journal of Language and Literature Studies

Osmanağa Mahallesi, Mürver Çiçeği Sokak, No:14/8

Kadıköy - ISTANBUL / TURKEY 34714

e-mail: editor@rumelide.com

phone: +90 505 7958124, +90 2167730616
} 
doğa da onlara iyilikler ihsan eder. Eğer böylesi bir kanaatkârlık ve teslimiyet olmazsa insanlar kötülüğe yönelirler.

İskender, bu gördüklerinden sonra bunun bir ibret olduğunu ifade eder ve "Dünyayı gezişim, artık yeterdir” (Şen 2019: 494) der. Bu ifade Nizâmî’nin Hamse'sinin de anlamını gösteren bir dizedir. Çünkü Hamse'nin son kitabı olan İskendername bir yönüyle bir yolculuk metnidir. Bilindiği üzere tasavvufi bir anlayışa sahip olan Nizâmî̀nin zihninde yolculuğun manası insanın dünyadaki yolculuğudur. Bu nedenle İskendername insan için amaç ve hedefin ne olduğunu gösteren bir kitaptır. Aranan marifeti ve sırrı ifade eden bu yaşantının merkezinde ise bütün insanların eşit olduğu ve birbirine üstünlük taslamaması gerektiği inancı vardır. İnsanı yüce kılan şey onun aklı ve ahlakıdır. Yoksa o bir hayvandan farklı değildir. Ulaşılması gereken hedef bu hayalî ülkede gördüğümüz barış, kardeşlik ve eşitlik hâlinde yaşamdır ve bu ancak insanların iyi bir ahlaka sahip olmalarıyla mümkündür.

\section{Sonuç}

Büyük şair Nizâmînnin Hamse'si estetik açıdan büyük bir öneme sahip olduğu kadar felsefi açıdan da kıymete değerdir. Burada bir ahlak ideali anlatılır ve bu ahlak idealinin temelinde insanlar arasında eşitlik vardır. İnsanlar arasındaki eşitlik onun diğer felsefi düşünceleriyle bütünlüklüdür. Eğer kişi Allah'ın mutlak varlık olduğunu ve diğer varlıkların ona muhtaç olduğunu kabul ederse zaten kendisini üstün göremez. İnsanın üstün bir yönü varsa o da aklı ve ahlakıdır. Şairler ve filozoflar insanlara güzel ahlakı anlatmalı ve aynı zamanda hayatlarını da buna göre düzenlemelidir.

Nizâmî’ye göre Allah bir varlık zinciri ile bütün varlığı birbirine bağlamış ve canlılı̆̆ı da bu nizama tabi kılmıştır. İnsan, ayağı çamurda başı göğe doğru yönelmiş bir canlı olarak bu nizamı gördüğ̈̈ nispette yücelik kazanabilecek bir varlıktır. Bu yüceliği görmesi ise söz ve akıl ile olanaklıdır. Bu nedenle o ideal sözü arayan bir düşünceden bahseder ki bu bir tür şiir ve felsefenin buluşması anlamına gelmektedir. Sözü en yüksek mertebede diye tanımlayan Nizâmî söz erenlerini birer sır perdesi, peygamberin ışığından bir gölge şeklinde değerlendirir. Onun için bilgide en yüce makam Tanrıya aittir ve filozofun bilgisi elbette sınırlıdır. Ancak insanlar için en iyi yaşam ancak ideal bir ahlak ile bu ise kanatkâr bir yaşam ile olanaklıdır.

Nizâmî’nin eserlerinde sıklıkla karşılaşılan felsefi yön İskendername'de daha yoğun ve bütünlüklüdür. Burada toplumsal hayata dair bir inanç ortaya koyan şair, ideal bir devlet tasvir ederken bunun ancak ideal insanlarla mümkün olduğunu savunur. Zira tasvir ettiği toplumda kişiler Allah’a tam bir iman ve teslimiyet içindedirler. Bu nedenle de onun tasarladığı ütopya düzeninde mülkiyete yer yoktur. Bu ütopya devletinde, kötülük düşünmeyen, paylaşmayı bilen insanlar yetinmeyi bildikleri için Tanrı karşısındaki kul olma eşitliğini toplumsal hayatta da görür ve gözetirler.

Nihayetinde, Nizâmı̂’nin felsefi düşüncesi daha çok ahlak ekseninde olmakla beraber şiirinin arka planında her zaman ontolojik tezler mevcuttur. Nizâmînnin evrenin nasıl bir düzene sahip olduğu ve bilginin dereceleri konusunda çoğunlukla döneminin filozoflarından Fârâbî̀yi takip ederek bu düşüncelerini geliştirdiği anlaşılmaktadır. Onun eşitlik tezi de yine büyük olasılıkla Fârâbî’nin etkisinde şekillenmiştir. Tıpkı Farabi gibi o da insanların erdemli olmalarıyla iyi bir toplumsal yaşama kavuşulabileceğini savunur. Burada temel ilkenin ise Tanrı karşısında itaatkar kul olma bilinciyle ortaya çlkan bir eşitlik olduğunu düşünür.

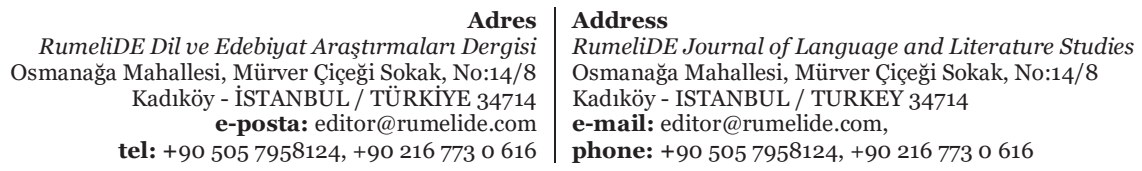




\section{Kaynakça}

Bilgen, A. (2018). Nizâmî’nin Hamsesindeki Eğitici ve Öğretici Nitelikteki Öğütler. Ankara Üniversitesi Dil ve Tarih-Coğrafya Fakültesi Dergisi, 35 (1).

Gençosman, M. N. (2014). Mahzen-i Esrar, Nizamî. İstanbul: Ataç Yayınları.

Kanar, M. (2007). Nizâmî-i Gencevî. Türk Diyanet Vakfi İslam Ansiklopedisi, İSAM, C. 33.

Morris, J. W. (2015). Kalp Aynası: İbnü'l-Arabi’nin Fütuhatü’l-Mekkiyye’sinde Manevi Aklın Keșfi. (Çev. Mustafa Çakmaklığlu). İstanbul: İnsan Yayınları.

Nahmedov, A. Saygın, T . (2012). Doğu'dan Bir Ütopya Kenti: Genceli Nizâmî’nin İskendername Eserinde İdeal Kent. İdealkent, 3 (5),124-135.

Nifferi, A. (2017). Mevâkıf. (Çev. Nurullah Koltaş). İstanbul: Büyüyenay Yayınları.

Özgen, M. K. (2020). Gılgamış Destanında ve Mistisizimde İçsel Yolculuk . KARE, (9).

Quluzade, Z. (2004). “Kamillik Zirvesi”. İskendername. İkbalname içinde. Bakü: Lider Neşriyat.

Rzaquluzade, M. (2004). Nizami Gencevi: İskendername, İkbalname. Bakü: Lider Neşriyat.

Şen, Y. (2019). Nizami Gencevi İskendername, Şerefname ve İkbalname. (Şerefname'yi Farsçadan Tercüme Eden: Abdullah Şaik; İkbalname'yi Farsçadan Tercüme Eden: Mikail Rızaguluzade; İzahların Yazarı: Ekrem Cafer). İstanbul: Zengin Yayıncılık.

Schimmel, A. (2013). İki Renkli Strma. (Çev. Can Özelgün). İstanbul: Alfa Yayınları.

Sevsevil, S. (2012). “Önsöz”, Hüsrev ile Şirin’e önsöz. İstanbul: Kabalcı Yayıncılık.

Sevsevil, S. (2012). Hüsrev ile Şirin: Nizâmi. İstanbul: Kabalcı Yayıncılık.

Tokmak, N. (2013). Nizâmî-yi Gencevî: Leylâ ile Mecnun. İstanbul: Say Yayınları. 